\title{
Foreign Institutions in the Civil Code of the Russian Federation: Analysis, Problems, Development Trends
}

\author{
Liudmila Yu. Vasilevskaya* \\ Kutafin Moscow State Law University (MSAL) \\ 9 Sadovo-Kudrinskaya Str., Moscow, 123995, Russia
}

Received 13.04.2017, received in revised form 05.05.2017, accepted 18.05.2017

The article examines the main institutions of foreign law that appeared in Section III of the Civil Code of the Russian Federation as a result of the law of obligations reforming. Analysis of the regulations concerning estoppel, astreinte, indemnity, warranties, termination fee, opposabilite du contrat, waiver and injunction made it possible to identify not only the features of their legal constructions, but also to show gaps, contradictions and shortcomings in the regulation of these institutions.

A comparative legal analysis of the new rules of the Civil Code of the Russian Federation and similar foreign rules demonstrated that the institutions developed in the jurisprudence of the countries of case law and based on terminology and the conceptual system being alien to Russian legal order cannot enter Russian civil legislation with ease. For example, considering estoppel in disputing a deal or claiming its invalidity under Items 2 and 5 of Art. 166 of the Civil Code of the Russian Federation, the author comes to the conclusion that unscrupulous contractors can use the principle of estoppel to make contracts with terms that are illegal in their content. Identifying the features of the legal status of indemnity under Art. 406.1 of the Civil Code of the Russian Federation, the author finds out that Russian civil legislation has a provision according to which one contracting party assumes a chargeable risk for those consequences that are not related to its actions for the proper fulfillment of the obligation. Risk taking requires an answer to questions not connected to liability issues. Unfortunately, the relations of the parties to the agreement on possible restrictions on the risks concerning loss compensation that the contracting party must take (not take) have not been settled in the Civil Code of the Russian Federation yet.

Keywords: estoppel, indemnity, reimbursement of the creditor's losses, assurances about the circumstances, losses, risks, creditor, debtor, deal, contract, impossibility to perform the obligation, convalidaton of the transaction, breach of obligation, unilateral refusal to perform the obligation, refusal to exercise the right, liability, transaction invalidity, negative obligation.

DOI: 10.17516/1997-1370-0087.

Research area: law.

Reform of civil legislation, in our view, cannot but cause some anxiety regarding the evaluation of the introduction of certain foreign institutions in the Civil Code of the Russian Federation (hereinafter referred to as the RF Civil Code), since it concerns the rapid strengthening

(C) Siberian Federal University. All rights reserved

* Corresponding author E-mail address: liudmila.vasilevskaya@gmail.com 
of Anglophile sentiments in the Russian civil law study in relation to foreign institutions, introduced in section III of the RF Civil Code "The general part of the law of obligations". This refers to the appearance of such obligations in the RF Civil Code as astreinte (Article 308.3), termination fee (Article 310), injunction (Article 393), indemnity (Article 406.1), warranties (Article 431.2), opposabilite du contrat (Article 433), waiver (Article 450.1), etc. Despite the foreignness of this experience (primarily of the Anglo-Saxon origin) for the legal system of Russia, these obligations have become indispensable in the RF Civil Code.

At the same time, it should be borne in mind that Russia possesses a unique legal system that is not compatible with any legal system related to the Anglo-Saxon legal system, so thoughtless copying and imitation will inevitably lead to a lot of problems in law enforcement practice. For example, among the "Anglophile" amendments one can come across a whole list of so-called "estoppels", which have already been introduced in the RF Civil Code. It is known that the action of the estoppel principle was approvingly accepted by many Russian civilians in explaining the amendments to Art. 166 RF Civil Code (on the convalidation of invalid deals). Meanwhile, this principle as prohibiting contradictory behavior was viewed in the doctrine as one of the key moments of the obligation law reform and as a clarification of the conscientiousness principle. However, the practice showed us the reverse outcome: unscrupulous contractors began to enter into contracts with illegal and defective terms. And thanks to the estoppel principle, when one of the contractors performs the obligations, the contract is not disputable. Thus, the desire of the legislator to protect the bona fide contracting party can result, as shown, in undesirable negative consequences.

In our opinion, the legal mechanism of the estoppel principle is not based on the right of the bona fide party to recognize a potentially insignificant deal as valid, but on depriving an unfair party of the right to file a claim for its invalidity in the case when its conditions are fully or partially executed by the other party. Besides, the estoppel principle does not take into account whether such compliance of obligations is performed by fair or unfair party, rather it is important that the terms of the transaction have been executed, since the actions of the contracting party testify to declaration of its intent. What is the clarification of the conscientiousness by the estoppel principle in this case?

In addition, there is one more circumstance that is not taken into consideration in the case of estoppel, i.e. the probable situation in which both contracting parties act unscrupulously. And in this case, it is not always possible to apply the norms of Art. 10 RF Civil Code, since if the deal may be considered as insignificant, the application for invalidity of the deal has no legal value, if the person referring to the invalidity of the deal acts unscrupulously (Item 5 of Art. 166 RF Civil Code). However, the reference to the norm of Art. 10 RF Civil Code concerning signs of the deal's invalidity means that one of the contracting parties abuses the right to recognize such a contract as invalid. And this, so far as is known, contradicts to the very nature of the insignificant deal, since the deal is insignificant regardless of the party's application.

It is crucial to pay attention to the fact that the emergence of the estoppel doctrine was largely due not only to the lack of a general concept of conscientiousness in English law, but also to the need to "soften" the concept of consideration in the Anglo-Saxon law system. Concurrently, the Russian legislator ignored the fact that there is no unity of approaches to understanding the essence of estoppel in various Anglo-Saxon legal systems. For instance, unlike English law, in which the law of individual estoppels is developed, Scottish law 
stipulates the provisions of the "personal bar" instead of the estoppel principle, with the former acting as an analogue of the abuse of right in the continental law system ${ }^{1}$.

Let us consider another institution associated with the norm of Art. 308.3 RF Civil Code on astreinte. Initially, the developers of the draft Federal Law No. 47538-6 "On Amendments to Parts One, Two, Three, and Four of the Civil Code of the Russian Federation, as well as to certain legislative acts of the Russian Federation" (hereinafter referred to as the draft bill) rightly considered it premature to introduce astreinte into the RF Civil Code, since it was important to work out the question of the compliance of the analyzed institution with the rules of procedural law, in particular, the provision on changing the order and method of the decisions' execution, if there is payment in kind. For example, a certain amount of money shall be paid in the event of the debtor's default. Notwithstanding this decision of the court, the plaintiff can file a petition for changing the order and method of execution of the decision demanding repaying this sum in the amount of the performance cost. A court herewith must also decide on the sum for non-fulfillment of the obligation in kind on a certain progressive scale. Obviously, with such an approach to the problem solving this may lead to an unjust enrichment of the creditor. This was not taken into account, since Art. 308.3 appeared in the RF Civil Code as a result of shadow amendments. In our opinion, one cannot admit that the decision to collect a monetary debt is tantamount to fulfilling a pecuniary liability in kind. It is also difficult to agree with the fact that this is a particular case of the dispute about fulfilling obligation in kind. For the sake of justice, it should be noted that this institution, borrowed from French law by the bill drafters, appeared in France due to its application in judicial practice for many decades.
Certain mixed feelings are also caused by the institution of indemnity, which has long been known in the Anglo-Saxon legal system and whish is now stated in Art. 406.1 RF Civil Code. In England, the United States, Australia, it is called "contractual indemnity", since it often acts as a condition for indemnity clause in various civil law contracts (agreements). In states of noncodified law, where common law operates, there is no definition of the indemnity concept in the law.

As a rule, in practice, counterparties formulate indemnity in the form of a specific condition of a civil law contract for the purpose of securing and protecting the creditor from adverse consequences under the circumstances provided for in the contract and specifying the grounds for the debtor recovering the property losses of the creditor. It is essential to emphasize that in the Anglo-Saxon legal system the issue of the debtor's fault does not have a significant meaning for the requirement of indemnity payment, more important is the occurrence of one of the circumstances specified in the contract. That is why indemnity is seen in the doctrine as "conditional indemnity", a "conditional" obligation that is independent, non-accessory from the main obligation arising from the contract, in connection with which an agreement on indemnity was concluded.

So, the question arises here: why does not the possibility of a claim for recovery of losses caused by the debtor's failure to perform or the debtor's improper performance exclude conditions for indemnity specified in the contract? In the doctrine this is explained by the fact that claims for damages and indemnity have a different legal nature, although in both cases this involves paying a certain amount of money. The first (demand for recovery of damages) is due to the nonfulfillment or improper fulfillment by the 
debtor of the contract's main obligation, while the second (requirement for indemnity) is due to the occurrence of the circumstances specified in the contract. Whereas the first requirement results from the main obligation that is violated (action for breach), the second results from an independent, "conditional" monetary obligation, under which the demand for payment of a specific monetary amount (debt claim) arises ${ }^{2}$. Finally, indemnity, in contrast to damages recovery, aims to return the creditor to the original property position and is permissible only if the debtor fulfills the main obligation implied by a specific civil law contract $^{3}$.

In particular, it should be mentioned that for all the apparent clarity in the differences and the relationships between indemnity and damages (compensation of losses and recovery of damages), the English doctrine highlights the concepts of "consequential damages" and "remoteness" of losses, which are not specified in the Russian law and civil law practice. The Russian law does not know such concepts and constructions as "remote losses", "punitive damages", "implied terms" of the contract for compensation of losses due to the statute or, in the light of the court decision, innominate terms of the agreement on indemnity, "exact protection" in indemnity, counter provision (consideration) for compensation of losses, etc.

It is known that English jurisprudence and doctrine have not only the methodology for determining the causal relationship between losses and the occurrence of circumstances specified in the contract, but also the procedure for determining the cause-effect relationship in cases of recovery of damages. In addition, there are certain methods for making such distinctions ${ }^{4}$. Russian law does not have such methods. This brings up the question: is it possible to borrow certain concepts existing in the norms of foreign law, take them out of the context of rules not known to our legislation and generally alien to the Russian law? Hardly so!

The first thing that needs to be paid attention to is the appearance of this institution in Chapter 25 of the RF Civil Code "Responsibility for Violation of Obligations", which is difficult to agree with. Unlike civil liability, which is a consequence of the debtor's unlawful behaviour, leading to negative property consequences for the creditor, the said institution has a different legal nature. Compensation for losses under Art. 406.1 RF Civil Code grants the creditor the right to demand this compensation also in the case when the debtor, together with proper fulfillment of the obligation, must by an agreement with the creditor compensate the latter for property losses that occurred upon the commencement of certain circumstances not related to the obligation breach. This means that in this case property losses, which by agreement of the parties can be assigned to one of the contracting parties, cannot be attributed to the losses. This implies additional means of protecting the creditor in the event of unpredictable circumstances, not related to the breach of obligations on the part of the debtor, but leading to the creditor's unforeseen expenses.

Consequently, the reimbursement of property losses under Art. 406.1 RF Civil Code and compensation for damages under Art. 15 and Art. 393 RF Civil Code cannot be equated. This means that the rules for calculating losses, formulated by the legislator in Art. 15 and 393 RF Civil Code, cannot be used to calculate the creditor's property losses (under Art. 406.1). In this connection, a number of questions arise. How do these concepts relate? Is it possible to consider compensation for the creditor's losses under Art. 406.1 RF Civil Code as a way to protect civil rights? If the last answer is positive, then what is the difference between this method of protecting civil rights from recovery of damages and a 
method of protecting civil rights, as set forth in Art. 12 RF Civil Code? How to determine the amount of compensation for the creditor's losses (under Art. 406.1), if the rules for determining the amount of such losses do not exist in the Civil Code of the Russian Federation (they have not been developed by judicial and arbitration practice)? The legislator does not answer the above mentioned questions.

As everyone knows, at the bill drafting stage there were fierce disputes over the inclusion of an article on indemnity in the RF Civil Code. According to V.V. Vitrianskii, the text of the bill article included some norms that allowed very cautious application of the new rules. ${ }^{5}$ In particular, as the author notes, when determining the amount of losses to be reimbursed there were to be used provisions of Art. 15 and 404 RF Civil Code, which would allow the court, if necessary, to reduce the amount of reimbursable losses if the creditor facilitated their increase (including by negligence) or had not taken reasonable measures to reduce losses.

The final wording of Art. 406.1 RF Civil Code does not contain "cautious" provisions from the bill. On the contrary, according to Item 2 of this Article, the court cannot reduce the amount of loss compensation, unless it is proved that the party requiring compensation has intentionally contributed to an increase in the amount of such losses. In this regard, note should be made of Clause 15 of the Resolution of the Plenum of the Supreme Court of the Russian Federation of March 24, 2016 № 7 "On the court application of certain provisions of the Civil Code of the Russian Federation on liability for obligations' breach" (hereinafter referred to as the Resolution of the Plenum of the RF Armed Forces), where it indicates that if the party claiming compensation for losses has unscrupulously facilitated the commencement of a circumstance agreed upon in the contract, then it is considered non- existent. Logically, a number of issues arise here. What are the criteria for stating that the contribution was unscrupulous? What exactly can the unscrupulous contribution express? Is it possible to consider the creditor's inaction in this situation of the unscrupulous contribution? What of the creditor's actions can serve as the basis for refusing to compensate losses? These questions remain unsolved.

In English law, the indemnity obligation, as indicated, can be qualified as a "conditional" obligation that is independent, non-accessory from the main obligation arising from the contract, in connection with which an agreement on indemnity was concluded. According to Item 3 of Art. 406.1 RF Civil Code and paragraph 17 of the Resolution of the Plenum of the Armed Forces of the Russian Federation, as a general rule, the completeness and validity of the agreement on compensation for losses are subject to an assessment by the court, regardless of the completeness and validity of the contract in connection with which it was concluded, even if this compensation is included in this contract in the form of its condition (clause). For example, if the loss compensation agreement is included as a condition in the supply contract, the invalidity or incompleteness of this supply contract do not by themselves entail the invalidity or incompleteness of the loss compensation agreement. It is easy to see similar provisions on compensation for losses associated with the overall assessment of the agreement on indemnity: under Russian and English law, the obligation to recover losses arising from an agreement (clause) does not depend on the main obligation.

However, in English law, this non-accessory obligation on indemnity, as a rule, is manifested in "independence" from the debtor's main obligation to recover losses. In Russian law, this "independence" is different: it is in the absence of coherence between the completeness and validity 
of the agreement on compensation of losses with the completeness and validity of the contract, in connection with which it (that is, the agreement on compensation of losses) is concluded.

In addition, the invalidity of deals under Russian and English law gives rise to various legal consequences. A voidable contract under English law may be enforced by bringing the action to a court, but a party has the right to insist on its cancellation due to capacity or other circumstances deserving consideration. Unlike a disputable (voidable) contract, a void contract does not create legal consequences for the participants: there is no valid contract, therefore it is impossible to enforce actions through the court. With a void contract, rules on restitution cannot be applied. In this regard, we may mark out that the institution of restitution is known to all modern law systems, but in many legal systems this institution is identified with the institution of unjust enrichment. So, in particular, the AngloSaxon law system uses the principle of gain-based theory in relation to restitution. For example, in 1951 the English professor John Dawson wrote that the right to restitution in England is a vivid example of a frozen theory, especially as regards the theoretical scientific development ${ }^{6}$. In 1979, G. Palmer, considering the institution of restitution in the United States, noted that the attitude of lawyers to restitution is not as hopeless as in England, since the right to restitution is still in its infancy in the United States? ${ }^{7}$. Despite the recent interest in the institution of restitution in the English and American doctrine, the jurisprudence still has seen only insignificant number of cases in which the independence of restitution as a legal institution was officially recognized $^{8}$.

Evidently, the borrowing of certain provisions on indemnity is unlikely to be useful for our law, since it will require the amendment and supplementation of a number of articles of the RF Civil Code. However, it should not be forgotten that many specific issues related to indemnity in the face of case law are resolved in England and the United States at the discretion of the court. Thus, introducing the rules on losses compensation in the RF Civil Code, we, in essence, as A.L. Makovskii pointed out, adopt a completely new approach to some cardinal positions, to the basics of our civil law'. Russian law of obligations has traditionally been built and based on the division and addition of such concepts as "responsibility" and "risk". In Art. 406.1 RF Civil Code, one can see an institution appears where one contracting party, in spite of the proper fulfillment of the obligation, assumes a chargeable risk for those consequences that are not related to its no-fault actions. Apparently, it is an institution similar to the institution of insurance. Clearly, it is not accidental that in English law insurance is one of the types of contract for indemnity, where the indemnity obligation is an obligation of "internal insurance", under which risks not related to the contract breach are insured not by an insurer (a third party), but by the contracting party.

If we analyze the norms of Art. $406.1 \mathrm{RF}$ Civil Code from the "point of view" of Chapter 48 RF Civil Code ("Insurance"), we will get many tasks that the legislator has not solved. Risk taking requires answering questions other than questions of responsibility. For example, given that there is a clause on compensation for losses in the contract, why, aren't the relationships between the parties specified, if they concern possible restrictions on the risks that the contracting party has to accept (not accept)? What is the essence of these possible restrictions? What risks, depending on this or that circumstance, may enforce these restrictions? There are no answers to these questions in the RF Civil Code.

It is known that judicial practice in the countries of case law introduced new rules 
gradually, including the rules on indemnity, for the regulation of relationships in civil circulation. For many years, by a trial and error method, a sufficiently sophisticated mechanism for loss compensation was worked out. It involves a balance of the contracting parties' interests. The introduction of similar rules into the law presupposes serious preparatory work, first of all, the compliance of new norms with other law norms, and which our legislator has not taken care of in connection with the RF Civil Code.

Having appeared in Art. 431.2 RF Civil Code, a new institution of assurances of circumstances (warranties) as a kind of protection against lying in contractual relations also deserves our attention. According to Art. 431.2 RF Civil Code, a party that, upon concluding a contract, either before or after its conclusion, has provided untrustworthy assurances to the other party about circumstances relevant for the conclusion, performance or termination of a contract, provides a remedy for breach of a warranty; so it entitles the aggrieved party to damages from the warrantor or, if stipulated in the contract, a penalty.

This institution has also been borrowed from the Anglo-Saxon law system, in which warranties and representations are treated as reports of facts relevant to the deal. We can speak about a wide variety of data: on the financial stability of the counterparty and the absence of tax debts, the presence of the representative's authority, the availability of title documents to the property of the counterparty. Noticeably, sanctions are established in this case not for non-fulfillment or improper fulfillment of the obligation by the counterparty, but for these unreliable allegations, which have caused the losses of the other contracting party.

In practice, the main problem, in our opinion, may follow the consequences of issuing false warranties in the form of civil liability, since the latter is connected with the legislative presumption introduced in paragraph 3 Item 1 of Art. 431.2 RF Civil Code (see also paragraph 2 of Item 4 of the said article). Responsibility occurs if the party that provided false warranties had known that the other party would rely on them, or had had reasonable grounds to make such an assumption. This means that the court shall be forced to determine the reasonableness of the grounds in relation to a particular dispute in each case. However, if it is very difficult for a person whose right has been violated to obtain damages in court (as evidenced by court-arbitration practice), it will be even more difficult, in our opinion, to prove the need to bring to justice the party having provided unreliable assurances, once the reason-based grounds criterion has been applied.

The good intentions of the legislator to remove from the shadows those circumstances that may have significant significance for the conclusion, execution or termination of the contract and about which one of the contracting parties would prefer to keep silent, are certainly worthy noticing. The prosecution of the party that has provided false warranties about certain circumstances means nothing more than an expansion of the list of grounds for bringing persons to civil liability. Nevertheless, legal force of warranties is enshrined in the RF Civil Code without taking into consideration the distribution of the consequences of their unreliability: it is not clear what unreliable warranties shall result in the refusal of the contract only, and in which cases it is necessary to claim damages or collect penalties only. In our opinion, the lack of clear, objective criteria for assessing the unreliability of warranties can be conducive to chaotic judicial practice, and instead of ensuring predictability of a judicial decision - to its injustice.

Perhaps the only institution whose analogue exists in French law (opposabilite du contrat) 
does not raise any objections. It is in the novel in Item 3 of Art. 433 RF Civil Code, according to which an agreement subject to state registration is considered concluded from the moment of its registration not for its parties, but for third parties, unless otherwise is stated by law. Therefore, if there is no state registration of the contract, then for a third person this means the absence of the contract. The contracting parties in relations with third parties cannot invoke the fact that they have entered into a contract which has not yet got the state registration. But notwithstanding this, in relations with each other, the creditor and the debtor cannot refer to the absence of state registration and, as a consequence, to the nonconclusion of the contract. In their relations the contract entails legal consequences from the moment when the parties reached an agreement on all essential conditions. To be fair, we shall remark that this position (even before the introduction of amendments to the RF Civil Code) was adhered to by the RF Supreme Arbitration Court $^{10}$.

In this regard, we should pay attention to the provision of Item 61 of the Resolution of the Plenum of the RF Armed Forces No. 2511, in which it is indicated that the party actually executing the deal before its necessary state registration has no right to refer to the expiry of the limitation period on the demand of the other party concerning its state registration (Item 2 of Art. 10, Item 3 of Art. 433 RF Civil Code). The reference to Item 3 of Art. 433 RF Civil Code is puzzling, since the regulation of Item 3 of Art. 433 RF Civil Code has nothing to do to the defendant's statement about the plaintiff's running of limitation period in the dispute over the deal's state registration. It would be another matter if a dispute erupted in connection with the non-fulfillment or improper fulfillment of an obligation arising from a contract for which no state registration was made, when the defendant, in order to refute the plaintiff's claim, for example, for damages, would refer to these circumstances. In this case it would be quite reasonable to refer to this regulation.

It is worth mentioning that the novel in Item 3 of Art. $310 \mathrm{RF}$ Civil Code concerns the right to unilateral refusal to fulfill the obligation or unilateral change of its terms, when the obligation is connected with the implementation of entrepreneurial activity by its parties. By agreement of the parties this subjective right can be determined by the need to pay a certain amount of money to the other party.

This regulation was also borrowed from the Anglo-Saxon law system, in which the contractual right to terminate it (termination fee) is due to the need for payment.

It is widely acknowledged that in Russia there has long been a practice when entrepreneurs envisaged payment for unilateral refusal to perform the contract, but courts used to qualify such a contract term as invalid or qualified this payment as another civil law institution: compensation or penalty. In our opinion, the payment for unilateral refusal to fulfill the obligation cannot be qualified as penalty, since its recovery is a measure of civil liability applied to the offender. Unilateral refusal provided by the contract terms is a lawful act, therefore the exercise of the right to unilateral refusal to fulfill the obligation cannot be considered as an unlawful action of the contracting party.

Of particular interest is such institution as waiver (Item 6 of Art. 450.1 RF Civil Code). It concerns the right of a party engaged in entrepreneurial activity to refuse to exercise its right. This applies not to any right, but only to the one that is generated by the contract (subjective contract right) and arises upon the occurrence of specific circumstances (grounds) provided for by the RF Civil Code, other rights, other legal acts or 
the contract itself. This means that if the parties, before concluding the contract, have decided to restrict their certain rights, then, in our opinion, it would be more appropriate to foresee a negative obligation, that is, an obligation with negative content, the essence of which is an act of omission concerning the action specified in the contract.

If a party declares its refusal to exercise such a right after the commencement of certain circumstances, then it will no longer be able to use this right in the future for the same reasons. Exception is made when similar circumstances come again. These regulations are dispositive. The legislator has established special rules when the claimed refusal of the right entails the termination of this right (that is, this rule is applied if the contracting party expressly declares the renunciation of its subjective contract right). However, even in this case it is not clear in what form this statement should be made, since the legislator is silent about this. Thus, the legislator has departed from the general rule, according to which the renunciation of citizens and legal entities to exercise their rights does not entail the termination of these rights, except in cases provided for by law (Item 2 of Art. 9 RF Civil Code).

This novel in Item 6 of Art. 450.1 RF Civil Code is designed to change the existing arbitration practice. It is known that before the introduction of this novel the courts, in fact, put a ban on the waiver of any subjective civil right, unless it was expressly permitted by law. Therefore, agreements which allowed for renunciation or restriction of law were often recognized as invalid.

Item 6 of Art. 393 RF Civil Code has a new regulation, which is an analogue of the institution of injunction in the Anglo-Saxon law system. The aforementioned article provides for the loss compensation procedure in case of non-fulfillment of negative obligations. In this case, in addition to compensation for damages caused, the creditor has the right to demand the termination of an action prohibited by virtue of the obligation. The law establishes that such a claim can be made even before breach of the obligation in the event of a real threat of such a violation. It should be noted that this norm is in Ch. 25 RF Civil Code, which deals with liability for breach of obligations. We believe that the legal effect concerning the realization of the creditor's right to demand the termination of the debtor's actions upon violation of a negative obligation can hardly be qualified as a measure of liability, since it (the legal effect) is not of property nature and can be exerted both after and before breach of the obligation. Naturally, if this measure is applied by the creditor after the debtor's breach of obligation, then it can be considered as a special way to protect the creditor's rights in case of negative obligation, and if the creditor resorts to this measure before breach of the obligation, it can be regarded as a measure to protect the creditor's rights.

The ambiguity in the interpretation of this rule has already been reflected in judicial and arbitration practice. For example, in one of the cases, the appellant pointed out that the disputable legal relations do not fall for Item 6, Art. 393 RF Civil Code, but for the rules of Art. 328 of this Code. Consequently, the suspension of the negative obligation fulfillment is an acceptable means of protecting the principal (the debtor in the obligation) $)^{12}$.

A brief analysis of the main foreign institutions allows us to conclude that the approach chosen by the legislator to consolidate them in the Civil Code of the Russian Federation should generally be qualified as hasty, not always thought out and generally imperfect. 
See also: Vasilevskaya, L. Yu. (2016). Interv'iu "Ia ne mogu skazat', chto nash GK stradaet ot nedostatka dispozitivnosti" [Interview "I cannot say that our CC suffers from a lack of disposability”], In Vestnik Arbitrazhnogo suda Moskovskogo okruga [Bulletin of the Arbitration Court of the Moscow District],1, 6-20.

2 See also: Macattram, G. How Can the Indemnity Clause Expand or Limit the Responsibility for Liability of the Parties in International Oil and Gas Contracts? available at: http://www.dundee.ac.uk/cepmlp/car/html/CAR10_ARTICLE2.PDF (date of access: 01 April 2017).

See also: Treitel, G.H. (1999). The Law of Contract. 10th ed. London, 864 p.

See also: Courtney, W. (2014). Contractual Indemnities. Oxford, Hart Publishing, 362 p.

See also: Vitrianskii, V.V. (2016). Reforma rossiiskogo grazhdanskogo zakonodatel'stva: promezhutochnye itogi [Reform of Russian civil legislation: interim results]. Moscow, Statut, $206 \mathrm{p}$.

6 See: Dawson, J. (1951). Unjust enrichment, 92-109 cit. ex.: Palmer, G.E. (1979). Book review, In Santa Clara Law Review, $19,1142$.

7 See: Dawson, J. (1951). Unjust enrichment, 92-109 cit. ex.: Palmer, G.E. (1979). Book review, In Santa Clara Law Review, 19, 1143.

8 See: Dzhanaeva, A.M. (2013). Evoliutsiia predstavlenii o restitutsionnykh pravootnosheniiakh v anglo-amerikanskom prave [Evolution of ideas about restitution legal relations in Anglo-American law], In Vestnik Federal'nogo Arbitrazhnogo suda Moskovskogo okruga [Bulletin of the Federal Arbitration Court of the Moscow District], 1, 111-126.

9 See: Makovskii, A.L. (2013). Ob urokakh reformirovaniia Grazhdanskogo kodeksa Rossii [On lessons of reforming the Civil Code of Russia], In Vestnik grazhdanskogo prava [Bulletin of Civil Law], 5, 157-172.

10 See: Resolution of the Plenum of the Supreme Arbitration Court of the Russian Federation of November 17, 2011 No. 73, paragraph 14; Information letter of the Presidium of the Supreme Arbitration Court of the Russian Federation of February 25, 2014 No. 165, paragraph 2, In Legal reference system ConsultantPlus: Judicial practice.

11 See: Resolution of the Plenum of the RF Armed Forces of June 23, 2015, No. 25 "On the Application by the Courts of Certain Provisions of Part I of Section I of the Civil Code of the Russian Federation", In Legal reference system ConsultantPlus: Judicial practice.

12 See: Decision of the Seventeenth Arbitration Appeal Court of 16.05.2016 No. 17AP-18805/2015-GK on case No. A5023711/2015, In Legal reference system ConsultantPlus: Judicial practice.

\section{References}

Arkhipova, A.G. (2012). Vozmeshchenie poter' v novom GK RF: za ili protiv? [Reimbursement of losses in the new RF Civil Code: for or against?], In Vestnik grazhdanskogo prava [Bulletin of Civil Law], 4, 158-183.

Belykh, V.S. (2016). Dogovornoe pravo Anglii. Sravnitel'no-pravovoe issledovanie [Contract law in England. Comparative legal research]. Moscow: Prospekt, 205 p.

Courtney, W. (2014). Contractual Indemnities. Oxford, Hart Publishing.

Daniels, M. (1974). Substantive and Procedural Aspects of Indemnity Practice: A Practical View for California Lawyers, In Stanford Law Review, 26, 3, 577-584.

Dzhanaeva, A.M. (2013). Evoliutsiia predstavlenii o restitutsionnykh pravootnosheniiakh v angloamerikanskom prave [Evolution of ideas about restitution legal relations in Anglo-American law], In Vestnik Federal'nogo Arbitrazhnogo suda Moskovskogo okruga [Bulletin of the Federal Arbitration Court of the Moscow District], 1, 111-126.

Hodges, S. (2006). Law of Marine Insurance. London, Cavendish Publishing Limited.

Makovskii, A.L. (2013). Ob urokakh reformirovaniia Grazhdanskogo kodeksa Rossii [On lessons of reforming the Civil Code of Russia], In Vestnik grazhdanskogo prava [Bulletin of Civil Law], 5, 157-172.

Palmer, G.E. (1979). Book review, In Santa Clara Law Review, 19.

Treitel, G.H. (1999). The Law of Contract. 10th edn. London.

Vasilevskaya, L. Yu. (2016). Interv'iu “Ia ne mogu skazat', chto nash GK stradaet ot nedostatka dispozitivnosti" [Interview "I cannot say that our CC suffers from a lack of disposability"], In Vestnik Arbitrazhnogo suda Moskovskogo okruga [Bulletin of the Arbitration Court of the Moscow District], 1, 6-20. 
Vitrianskii, V.V. (2016). Reforma rossiiskogo grazhdanskogo zakonodatel'stva: promezhutochnye itogi [Reform of Russian civil legislation: interim results]. Moscow, Statut, 206 p.

York, K.H., Bauman, J.A., and D. Rendleman (1991). Remedies, Cases and Materials. 5th edn. St.Paul., West Publishing Co.

\title{
Иностранные институты в ГК РФ: анализ, проблемы, тенденции развития
}

\author{
Л.Ю. Василевская \\ Московский государственньй юридический \\ университет им. О.Е. Кутафина \\ Россия, 123995, Москва, ул. Садовая-Кудринская, 9
}

В статье рассматриваются основные институты иностранного права, появившиеся в разделе ІІІ ГК РФ в результате реформы обязательственного права. Анализ норм об еstoppel, astreinte, indemnity, warranties, termination fee, opposabilite du contrat, waiver, injunction дал возможность не только выделить особенности их правовых конструкиий, но и показать пробелы, противоречия и недостатки в нормативной регламентачии указанных институтов. Сравнительно-правовой анализ новых норм ГК РФ и аналогичных иностранных правил показал, что институты, развитые в судебной практике государств прецедентного права и опирающиеся на терминологию и чуждый нашему правопорядку понятийный аппарат, не могут без издержек быть рецепированы российским гражданским законодательством. Например, рассматривая еstoppel при оспаривании сделки или заявлении о ее недействительности по п. 2 и $5 \mathrm{~cm} .166$ ГК РФ, автор приходит к выводу, что недобросовестные контрагенты могут использовать принцип еstoppel для заключения договоров с незаконныли по своему содержанию условиями. Выявляя особенности правовой конструкции indemnity по ст. 406.1 ГК РФ, автор делает вывод, что в нашем гражданском законодательстве появился институт, согласно которому одна сторона договора принимает на себл возмездное несение риска за те последствия, которые не связаны с ее действиями по надлежащему исполнению обязательства. Несение риска требует ответа на вопросы, не связанные проблемами ответственности. К сожалению, отношения сторон договора по возможным ограничениям в части рисков, которые обязана принять (не принять) та или иная сторона договора, в котором есть оговорка о возмещении потерь, в ГК РФ не урегулированы.

Ключевые слова: estoppel, indemnity, возмещение потерь кредитора, заверения об обстоятельствах, убытки, риски, кредитор, должник, сделка, договор, невозможность исполнения обязательства, исиеление сделки, нарушение обязательства, односторонний отказ от исполнения обязательства, отказ от осуществления права, обязательство, недействительность сделки, негативное обязательство.

Научная спещииальность: 12.00 .03 - гражданское право. 